\title{
Effective suggestive psychotechniques in the political media discourse
}

\author{
Nadezda N. Volskaya - Liudmila A. Borbotko - Marina R. Zheltukhina - \\ Milana E. Kupriyanova - Anna Yu. Ilina
}

\section{DOI: 10.18355/XL.2017.10.04.08}

\begin{abstract}
The article analyzes some effective suggestive psychotechniques in the political media discourse. The analysis of material shows active use of suggestive psychotechniques in the contemporary political media discourse. It is established that suggestive psychotechniques play a significant role in the media discourse, promoting formation of ideological behavior models of the mass communication texts consumer. Suggestive psychotechniques in the political media discourse, influencing person's consciousness, do not create new needs. Their effectiveness is manifested in the decision-making process. Thus, something is always compared presented to consciousness and being beyond its limits. Suggestive process of influence on mentality of the addressee, on his feelings, will and reason connects with decrease in consciousness, analyticity and criticality at perception of the inspired information. Suggestor seeks to enter the addressee into a certain state and to induce to certain actions. The article identifies and describes some effective suggestive psychotechniques in the political media discourse: 1) concreteness and figurativeness of keywords, 2) concreteness and figurativeness of qualities, 3) phonosemantics, 4) full uncertainty and unpredictability, 5) illusion of choice, 6) presupposition.

Key words: mass media, media discourse, political media discourse, influence, media effects, suggestive psychotechniques.
\end{abstract}

\section{Introduction}

Media discourse as a sociocultural product is characterized by the social and cultural identity, which is especially actively shown in the border area of media discourse and political discourse. In this interrelation, the ideology forming the public opinion allowing excluding certain social groups and individuals from active political and cultural public life is realized.

One of the most important directions of linguistics is the cognitive linguistics considering language as a cognitive tool, as a system of signs representing (coding) and transforming information (Kubryakova, Demyankov, Pankrats, 1996: 53).

The aim of the study is to identify effective psychotechniques of suggestive media influence in political communication. We need to analyze and compare the contents and means of suggestive media influence in political media texts.

The overarching research question of this study was as follows:

How can we identify effective psychotechniques of suggestive media influence in political communication?

\section{Theoretical research base: condition of problem's study}

Because the humanity in the XXI century is in a phase of information space glut and information pressure, the media discourse has a huge influence on the public consciousness (Thomson, 1977; Alesandrini, 1983; Merritt, 1984; Vol'f, 1986; Alwitt, Deighton \& Grimm, 1991; Biocca, 1991; Johnson-Cartee \& Copeland, 1991; Golanova, 1993; 1997; Aberncthy, 1992; Faber, 1992; Englis, 1994; Kaid \& HoltzBacha, 1995; Jamieson \& Campbell, 1997; Chaldini, 2001; Pochepcov, 2001; Verdonk, 2002; Zheltukhina, 2003; Witosh, 2005; Plotnikova, 2008; Vol'skaya, 2008; 
Ilyina, 2013; Karasik, 2013; Zheltukhina, 2014; Il'ina \& Kupriyanova, 2016; Kupriyanova et al., 2016; Zheltukhina et al., 2017a, Zheltukhina et al., 2017b; Zheltukhina et al., 2017c; Zheltukhina et al., 2017d; Zyubina et al., 2017e). The majority of representations and knowledge of the world is formed at the person under the influence of mass media (television, radio, press, Internet). In the mass media discourse, suggestive psychotechniques are actively used.

\section{Methodological bases and research methods}

The research aim has defined the choice of methods of our analysis. In work, we apply the following methods: inductive, descriptive and comparative, cognitive and discursive, semantic, definitional, functional and stylistic analysis.

The methodological basis of research is a system approach. According to the principles of system approach, any phenomenon (suggestive media influence) is considered as integrity in unity of all its communications and relations. In order to distinguish which structural and content features are in the analyzed publications comparative and quantitative analysis (content analysis) of political media texts was carried out.

The methods of the study contain a comparative discourse and semantic analyses of contents and means of suggestive influence in political media texts. The ways of analysis are useful for development of psycho- and sociolinguistics, linguapragmatics, cultural linguistics, media and political linguistics, comparative linguistics, communication theory, influence theory.

As material of the research, media texts in political communication of the XX-XXI centuries are used.

\section{Results and Discussions}

In our research, we prove a hypothesis that a media addresser uses suggestive psychotechniques in political media communication to influence on the addressee in most effective ways. We have to identify the effective directions of suggestive media influence in political media discourse.

Suggestive (lat. suggestio - suggestion) process of influence on mentality of the addressee, on his feelings, will and reason connects to decrease of consciousness, analyticity and criticality by perception of inspired information. The suggester aspires to lead the addressee into the certain condition and to induce to certain actions.

The subject managing suggestion process offers to the object of influence, suggestion the facts and the arguments bearing a suggestive charge that is installation of the suggester. The degree of suggestibility depends on a level of a susceptibility of the addressee to suggestion that is to his readiness to test inspiring influence and to obey him. Force of influence of the addresser depends on the following factors:

\section{Informational:}

1) Formal:

a) Information visibility (information effect on the eyes is very effective);

b) Information availability (the information is presented in simple language in the lexical and grammatical aspects, using gestures, signs).

2) Substantial:

a) Information importance degree (the more relevant the information, the higher the degree of its suggestibility);

b) Information logicality (the precise, logical information structure causes trust in the addressee);

XLinguae, Volume 10, Issue 4, October 2017, ISSN 1337-8384, eISSN 2453-711X 
c) Information certainty degree (the more uncertain the information according to content, the higher the force of suggestibility);

3) Procedural:

a) Information submission frequency (repeated repetition of information in different sources of mass communication in various interpretation promotes its assimilation and fixing in consciousness);

b) Information feed speed (with increase in feed speed of information the amount of time decreases for the analysis).

\section{Personal:}

1) Social suggester's status (than more authoritative the sender, the higher his social status, the more the trust of the addressee to him and to his words);

2) Inspired information conformity to addressee's needs and interests (the inspired information should be necessarily focused on the addressee, on his/her needs and interests).

\section{Mental:}

1) Mental conditions (stress, disease, fatigue blunt criticism of the addressee);

2) Mental qualities:

a) Emotional (impressionability, uncertainty, shyness of the addressee promote increase of suggestive force);

b) Intellectual (low self-estimation, logic analysis weakness, awareness low level, competence raise force of suggestion).

Distinctions in submission of the information material in mass media depend on socio-psychological specificities of the addressee as they define the argumentative strategy realized in texts of mass media.

Suggestive psychotechniques of the mass media discourse influencing consciousness of the person do not create new needs. Their efficiency is shown in decision-making process. Thus, something submitted to consciousness and taking place for its limits is always compared.

The information should be attractive subconsciously. It is known that the basis of its attraction is sexuality (Frejd, 1997). Mass media actively discuss this theme in life, politics, advertising, and use verbal and nonverbal means. We can give some examples of broadcasting and retransmitting tidbits, inflating of scandals, and advertising of production, etc. with invention of new words and expressions, use of colloquial lexicon, activization of nonverbal communication:

1) monikagejt-

Monicagate

(the American scandal about mutual relation of intimate character between Bill Clinton and Monica Levinsky).

2) chelovek, ochen' pokhozhij na general'nogo pokurorathe person very similar to the general public prosecutor

(the statement becoming a stamp: the person similar to..., causing in consciousness of the person the association with the known scandal caused by demonstration on RTR video recording with participation of general public prosecutor Jury Skuratov and of call girls, promoting removal of the general public prosecutor of the Russian Federation from his post).

3) Ne tormozi, snikersni!

- Do not brake, snickersake! (advertising of snickers).

4) Sdelaj fint... Pust' druz'ya zaviduyut. Tol'ko dlya tekh, kto pravda krut. Make a trick... Let friends envy. Only for those who is true reckless. (advertising of chocolate bar: Three young men are sitting on a bench. Ninka is going. Two 
enthusiastically are looking at her and expressing the sympathy. The third is indifferent, concluding "Not in my taste" and unwrapping a bar of chocolate "Trick" ("Feint").

5) One of subtitles of article "Love office" by Olga Tatarchenko: CHtoby pobedit' na vyborakh, nuzhna golova -

To win elections, the head is necessary.

The article is about the wife of Gerhard Shröder Doris Kopf. Her surname in translation from German Kopf means "head".

Gerkhard SHreder svoej pobedoj na vyborakh obyazan isklyuchitel'no sobstvennomu romanu. Ego predvybornyj marafon rifmovalsya s lyubovnoj melodramoj. Ukhod ot zheny, love story $i$ chetvertyj brak SHredera chrezvychajno vzbudorazhili nemtsev, ustavshikh ot dobrodetelej Gel'muta Kolya. I prinesli politiku post bundeskantslera...

I dalee:

$V$ politicheskoj mode otkormlennyj plejboj yavno nachal vytesnyat' dobrodetel'nogo semejstvennogo nemtsa. Gerkhardu SHrederu povezlo: zigzag ego lichnoj zhizni sovpal so smenoj prioritetov ehlektorata. Prichem, pokhozhe, SHreder sam ehto osoznal uzhe posle togo, kak zanyal vysokoe kreslo. -

Gerhard Schröder is obliged by the victory on elections to exclusively own love affair. His pre-election marathon was rhymed with the love melodrama. Divorce, love story and the fourth marriage of Schröder have extremely excited the Germans tired of Helmut Kohl's virtues. Also have brought a politician a post of Bundeskanzler...

Further:

In political fashion, the fattened playboy obviously has begun to force out the virtuous domestic German. Gerhard Schröder was lucky: the zigzag of his private life has coincided with change of priorities of electorate. Moreover, seemingly, Schröder has realized it already after holding a high post.

Further the signature under G. Shröder's photo:

Politiki tak $i$ ne ponyali, kak Germaniya mogla vybrat' kantslerom cheloveka, kotoryj sposoben khorosho rukovodit' tol'ko svoej izbiratel'noj kampaniej. - Politicians have not understood how Germany might choose as chancellor the person who is able well to lead only his election campaign. (Profile. Career, 6, 06.1999)

It is necessary to remember, that the latent sexual motives are better obvious. Redundancy of the last may irritate and cause the protest by the addressee who declines to hit upon and to dream.

The media widely address subconscious motives, being guided by the research results psychoanalysts. Mass media carrying out influence on the addressee frequently appeal to experiences of children's age and consider such functions of the personality as entertainment function (the internal child) and function of establishing order and respect for traditions (the internal adult, the parent), revealed by the transact analysis (Bern, 1988). Thus, in mass media discourse by inclusion of the child in adult plots and vice versa the relation "an internal part of the person - external urgent" realizes.

Return to children's models of behaviour of known Russian political figures (childishness, fieriness, discontent, "to sulk and not to talk", counteraction to authorities, persistence, children's memoirs etc.) all TV channels in releases of news

XLinguae, Volume 10, Issue 4, October 2017, ISSN 1337-8384, eISSN 2453-711X 
have clearly shown:

G. Seleznev: Vladimir Nikolaevich, vy ot ch'ego imeni vyprygivaete?

V. Lopatin: Uvazhaemyj, Gennadij Nikolaevich, ya dumayu, vam nado izvinit'sya za "vyprygivanie".

S.: No esli vy vyprygivaete? YA ved' skazal pravdu, vy dazhe podskochili.

L.: Tem ne menee ya prizyvayu vas soblyudat' parlamentskuyu ehtiku.

S.: $A$ vy ne prygajte, a podnimajte ruku. L.: $A$ vy podmechajte tekh, kto sidit na galerke.

- G.Seleznev: "Vladimir Nikolayevich, from whose name do you jump out?

V.Lopatin: Dear, Gennady Nikolayevich, I think, you should apologize for "jumping out".

S.: But if you jump out? I you see have told the truth, you even have jumped up.

L.: Nevertheless, I appeal to you to observe parliamentary ethics.

S.: And you do not jump, and lift your hand. L.: And you notice those who sits on gallery. (TV, 1996).

Political accusation of each other by means of the comic (from irony up to sarcasm) occurs as a result of infringement of stylistic compatibility by use of words and expressions of a lexico-semantic layer of children speech: vyprygivat', prygat', podnimat' ruku (kak v shkole), podskochili - to jump out, jump, lift a hand (as at school), have jumped up, in parallel to the lexicon appropriate to their social status: parlamentskaya ehtika, prizyvayu soblyudat' - parliamentary ethics, call to observe, etc., and also due to repeated recurrence of varied lexical units (vyprygivat', vyprygivanie, vyprygivaete, podskochili, ne prygajte - to jump out, jumping out, jump out, have jumped up, do not jump) at fast change of retorts. Influencing subconscious motives of the addressee, mass media after "harmless", at first sight, parliamentary comic "roller" with the appeal to children's models of behaviour quietly submitted any time the information not causing the seizure by audience.

There are various suggestive psychotechniques in the mass media discourse. In the article we describe the most important and the most frequency suggestive psychotechniques.

1) Concreteness and figurativeness of key words: Use of words, which sense it is concrete, which contents are easy for themselves for presenting, essentially raises effect of suggestion. Abstract concepts sharply reduce force of suggestion.

Oppozitsiya gotovitsya ob"yavit' pravitel'stvu SHAKHRAJ, ottaskat' ego za CHUBAJS i nadavat' po CHERNOMYRDIN.

"The opposition prepares to declare to government SHAKHRAY, to pull it off for CHUBAYS and to give on CHERNOMYRDIN".

(Komsomolskaya Pravda, 11.02.1995)

Concreteness and figurativeness of key words emotionally influences the addressee, creating the comic. In consciousness of the addressee there is a sharp frame-change "game in a chess", "hair", "a part of a body", "politician" or his "attribute". The comic effect takes place in connection with semantization of proper names in steady expressions (ob"yavit' shakh: SHAKHRAJ, ottaskat' kogo-l. za chub: CHUBAJS, nadavat' po morde: CHERNOMYRDIN "to declare a check: SHAKHRAY, to pull 
off for a forelock: CHUBAYS, to give on a muzzle: CHERNOMYRDIN), with formation on their basis of words-expressemes which value is equal to the negative, scornful relation of the subject of speech to the called phenomenon.

2) Concreteness and figurativeness of qualities: Use of words and expressions revealing qualities and properties of subjects and phenomena, giving concreteness to figurative concepts promotes increase of force of suggestibility. As an example, it is possible to result B. Yeltsin's statement about the relation of the State Duma to A. Chubays, repeatedly reflected in different mass media:

\begin{abstract}
$U$ nikh allergiya $k$ CHubajsu. Kto-to ne lyubit ryzhikh, kto-to chernykh, kto-to sedykh... Kto-to lysykh. A nam kak gosudarstvu gosudarstvo vazhnee.

"They have an allergy to Chubays. Someone does not like red, someone black, and someone grey-haired ... Someone bald. And for us as for the state the state is more important".
\end{abstract}

(TV, 1998; Arguments and Facts, 26, 07.1998)

B. Yeltsin protects himself, removes from himself criticism, recollecting A. Chubays. The comic is created as a result of infringement of presupposition of common sense, metonymical carry (a part / the whole), identification of himself with the state ( $A$ nam kak gosudarstvu "And for us as for the state"), and also transfers of originators, namely: red (Chubays), black (Nemtsov), bald (Kiriyenko) and grey-haired (himself). Uncertainty is removed due to that, the comic opens value of the statement due to use of identifying attributes of subjects and phenomena in the certain context. The subject and the phenomenon, as a rule, directly are not referred that promotes realization of the manipulative function. For example, words of A. Lebed are clear to all carriers of Russian, who is in a rate of political events in the country:

Nasha obshhaya ryzhaya radost'.

"Our general red pleasure".

(Komsomolskaya Pravda, 38, 06.03.1998)

Despite of abstractedness of the statement of A. Lebed, it is clear, that the question is quite concrete person A. Chubays. The word radost' "pleasure" is strongly sneered, as A. Chubays is not pleasure for people because of his activity (voucherization, privatization etc.). To decipher the sense of the told essential details of the description of this pleasure help: ryzhaya "red" - on colour of hair, obshhaya "general", that is known for everybody as he has tried for all people "on glory", Nasha "Our", that is Russian.

Metonymical carry "abstract concept, feeling - the person causing this feeling", amplified with concretizing adjectives obshhaya, ryzhaya "general, red" and a possessive pronoun Nasha "Our", creates the comic effect removing uncertainty. Thus, A. Lebed operates with neutral words, except for a word radost' "pleasure" with positive connotation, with the purpose to achieve opposite effect, having caused by means of irony negative emotion by the addressee owing to association of red colour with colour of hair of A. Chubays.

3) Phonosemantics: Purposeful influence on a person, on his/ her emotion may be carried out by means of the certain words and word collocations, which are capable to cause not only emotion, but also subconsciously to be perceived as any images. It is established, that presence or prevalence in words of a vowel $u$ " $e$ " causes impression

XLinguae, Volume 10, Issue 4, October 2017, ISSN 1337-8384, eISSN 2453-711X 
of something small or insignificant. The abundance of consonants, especially of hushing consonants impresses something gloomy, unpleasant-not-clear.

Razve ne vidno, chto pravitel'stvo soznatel'no burbulit i gajdarit, chubajsit $i$ shakhraet - Rossiyu dobivaet?

"Is it not visible, that the government conscious burbulits and gaydarits, chubaysits and shakhrayets - Russia finishes?"

(Day, 1992, 43)

In this case the heap of "gloomy" consonants "b,r,g,d,t,s,ch,sh,kh" and "insignificant" vowel " $i$ " would be observed. There is a duplication of the contents of the clot "activity" (burbulit', gajdarit', chubajsit', shakhrat' "to burbulit, to gaydarit, to chubaysit, to shakhrayet") of the frame "politician" and its curtailing up to the slot "activity" (dobivat' "to finish").

The effect of suggestion raises due to the comic arising as a result of transition of proper names Burbulis, Gaydar, Chubays, Shakhray by word-formation in verbal common nouns becoming members of one synonymic lines, formed by analogy with "finishes" (semantic repetition).

4) Full uncertainty and unpredictability: The addressee up to last moment does not guess, about what is there a speech in the message. His condition at this moment is very close to a condition of a trance. Received on such background of expectation in the audiovisual textual mechanism the clear instruction perceives by addressee positively:

Paren': Tebe kakie mal'chiki nravyatsya svetlen'kie ili temnen'kie? Devushka: Umnye, no vam ehto ne grozit. "Boy: What boys do you like: blond or dark?

Girl: Clever, but it does not threaten you". She is unwrapping "Feint" (advertising bar of chocolate "Feint").

Subconsciously would be desirable to get and try the promoted goods.

5) Illusion of choice: The non-existent alternative creating illusion of selection and decision-making is offered to the addressee.

U nas s vami odin vybor - libo vmeste dvigat'sya vpered, libo obnyavshis', kak zaklyatye druz'ya, pryamym khodom upiraemsya v ocherednoj istoricheskij tupik.

"We have with you one choice - or to move forward together, or having embraced as implacable friends, a direct course we rest against the next historical impasse". (V. Chernomyrdin) (Komsomolskaya Pravda, 187, 10.10.1997)

First, the comic forms owing to paradoxical replacement of the contents of the slot "intensity" of the frame "friend", namely: "a degree of friendliness", on the contents of the slot "intensity", namely: "a degree of animosities" of the frame "enemy" (zaklyatyj "implacable"). Second, presumably, V. Chernomyrdin subconsciously creates illusion of a choice as vmeste dvigat'sya vpered "together to move forward" and byt' zaklyatymi druz'yami "to be implacable friends" (the treatment "the most advanced stage of friendliness, that is friends are the same as well as sworn enemies" is possible) may act as contextual synonyms as advance may lead up a blind alley. 
6) Presupposition: In this psychotechnique, the command moves as preliminary action or condition for performance of any other action, less significant, than the necessary command, and easily meaningly supervised. Thus, the command of censorship of consciousness avoids. The mass media sender frequently uses in the speech aphorisms for the argument of any positions. Realization of the presupposition influences on the addressee is observed by the appeal to an aphorism due to discrepancy of the presuppositive and assertive parts of the statement of A. Lebed, who asserts the following:

\section{Russkikh net. Est' khorosho zabytye evrei i plokho otmytye tatary. "Russian is not present. There are well forgotten Jews and badly washed Tatars". \\ (Moskovskij komsomolets, 30.04.1998)}

Language playing up of the known aphorism Novoe - ehto khorosho zabytoe staroe "New is well forgotten old" creates the comic and plays on national feelings of the addressee, hiding installation of the sender against Jews and Tatars.

The study of literature and factual media material indicates on the presence of a theoretical framework on the issue of the most effective suggestive psychotechniques of media influence on the addressee in the political media discourse.

Mass media using suggestive psychotechniques operate people, who operates, frequently not realizing motives of the actions. By perception of the suggestive information, the consciousness of the addressee begins operating with a key word, a symbol, a sign etc. and determines behaviour of the person. Except the basic channel "text" carrying the message, there is a channel "collective unconscious", managing the communication and behaviour of all participants of mass media interaction. Thus, neither the mass media sender, nor the addressee in some cases does realize programming of mentality.

The projection of results of researches of consumer behaviour (USA) on mass media discourse allows give some suppositions of behaviour of consumers of mass media production. It is possible to allocate the following qualities of the mass media addressee:

\section{1) Impulsiveness:}

The mass media addressee makes the majority of the actions impulsively, that is involuntarily, under influence of sudden prompting, impulse.

\section{2) Traditional character:}

Mass media do not change belief of the addressee concerning an image of actions preferred to him. If the unusual, new for him situation is created, the addressee chooses such direction of actions about which it is constantly spoken in mass media.

\section{3) Transogenetic character:}

J. Vicary has established, that the person seeing the goods whom he intends to buy, becomes transfixed, ceases to blink and to swallow a saliva, his breath is slowed down, pupils extend, the sight becomes disfocal, that is to say he/her sinks into hypnotic trance. By the normal person eyes blink 32 times a minute, in strong excitement, pressure - 50-60 times, and in the weakened condition - a maximum up to 20. During selection of the goods, the number of blinking's falls up to 14 (Vicary quoted on: Mokshantsev, 2000: 122). Presumably, the person hearing and seeing close and habitual things in mass media discourse sinks into hypnotic trance too. 


\section{4) Associativity:}

Being a spectator, a listener or a reader of mass media products, the addressee declines to identify him / herself with a character of a plot of the printed text or film if they are picked up adequately. In other words, the mechanism of identification works. The real person acquires a behavioural pattern of the hero, his discourse and at collision with a similar situation behaves himself like character seen or drawn in imagination.

\section{Conclusion}

Therefore, it is important to emphasize that the political media discourse as a sociocultural product is characterized by sociocultural identity, which is especially actively shown in the sphere of media and political communication. In this interrelation, the ideology forming the public opinion allowing to exclude certain social groups and individuals of active political and cultural public life is implemented (Zheltukhina et al., 2017a). Suggestive psychotechniques play a significant role in the political mass media discourse, promoting formation of world outlook models of behaviour of the consumer texts in mass communication through PR and advertising.

It is necessary to note, that mass media discourse as sociocultural product is characterized by sociocultural identity, which is especially actively shown in boundary area of mass media and political discourses. In this interrelation the ideology forming a public opinion is realized, allowing exclude the certain social groups and separate persons from active political and cultural public life.

\section{Bibliographic references}

ABERNCTHY, A.M. 1992. The information content of newspaper advertising. In: Journal of Current Issues and Research in Advertising, vol. 14, n. 2, pp. 63-68. ISSN 1064-1734. E-ISSN 2164-7313.

ALESANDRINI, K.L. 1983. Strategies that influence memory for advertising communications. R.J. Harris (Ed.). Information processing research in advertising (pp. 65-82). Hillsdale, NJ: Lawrence Eribaum Associates. ISBN 9780803953512.

ALWITT, L.R. - DEIGHTON, J. - GRIMM, J. 1991. Reactions to political advertising depend on the nature of the voter-candidate bond. F. Biocca (Ed.). Television and political advertising: Vol. I. Psychological processes (pp. 329-350). Hillsdale, NJ: Lawrence Eribaum Associates. ISBN 0805806555.

Bern, Eh.L. 1988. Igry, v kotorye igrayut lyudi: psikhologiya chelovecheskikh vzaimootnoshenij. Lyudi, kotorye igrayut v igry: psikhologiya chelovecheskoj sud'by: per. s angl. Moskva: Progress. ISBN 5-7815-1788-X.

BIOCCA, F. 1991. Television and Political Advertising. Hillsdale, N.J.: Lawrence Eribaum Associates. ISBN 0805806555, 0805806628.

CHALDINI, R. 2001. Psikhologiya vliyaniya. Sankt-Peterburg: Piter. ISBN 5-31800218-8.

ENGLIS, B.G. 1994. The role of affect in political advertising: Voter emotional responses to the nonverbal behavior of politicians. E.M. Clark, T.C. Brock, \& D.W. Stewart (Eds.). Attention, attitude, and affect in response to advertising (pp. 223-247). Hillsdale, NJ: Lawrence Eribaum Associates. ISBN 978-1138876156.

FABER, R.J. 1992. Advances in Political Advertising Research: A Progression From if to When. In: Journal of Current Issues and Research in Advertising, vol. 4, n. 2, pp. 1-18. ISSN 1064-1734. E-ISSN: 2164-7313.

Frejd, Z. 1997. Ostroumie i ego otnoshenie k bessoznatel'nomu. Moskva: AST. ISBN 5-7914-0001-2.

GOLANOVA, E.I. 1993. Ustnaya publichnaya rech'. ZHanr publichnoj lektsii. Russkij yazyk v ego funktsionirovanii. Kommunikativno-pragmaticheskij aspekt. Moskva, pp. 137-157. ISBN 5-02-011112-0. 
IL'INA, A.YU. - KUPRIYANOVA, M.E. 2016. Lingvokul'turnoe svoeobrazie toponominatsij provintsii Britanskaya Kolumbiya. In: Vestnik RUDN. Teoriya yazyka. Semiotika. Semantika, n. 4, pp. 49-56. ISSN 2313-2299.

ILYINA, A.Y. 2013. Amerindian Toponymic Layer as a Constituent of Canadian Toponymic System: Science, Technology and Higher Education. In: Materials of the II International Research and Practice Conference. Vol. I. Westwood, Canada, pp. 421-424. ISBN 978-1-77192-012-4.

JAMIESON, K.H. - CAMPBELL, K.K. 1997. The Interplay of Influence: News, Advertising, Politics and Mass Media. Belmont, Ca: Wadsworth Publishing Company. ISBN 9780534533649.

JOHNSON-CARTEE, K.S. - COPELAND, G.A. 1991. Negative political advertising: Coming of age. Hillsdalc, NJ: Lawrence Eribaum Associates. ISBN 9780805808346.

JOHNSON-CARTEE, K.S. - COPELAND, G.A. 1997. Manipulation of the American voter. Political campaign commercials. New York: Praeger. ISBN 0275955885 .

KAID, L.L. - HOLTZ-BACHA, C. (Eds.). 1995. Political advertising in Western democracies: Parties and candidates on television. Thousand Oaks, CA: Sage. ISBN 9780803953529.

KARASIK, V.I. 2013. Yazykovaya matrica kul'tury. Moskva: Gnozis. ISBN 978-594244-043-5

KUBRYAKOVA, E.S. - DEMYANKOV, V.Z. - PANKRATS, YU.G. 1996. Kratkij slovar' kognitivnykh terminov. Moskva: MSU. ISBN 5-89042-018-6.

KUPRIYANOVA, M. - WAGNER, M. - DONSKAYA, M. - OVEZOVA, U. 2016. Perspectives of Introduction of the Mobile-Assisted Language Learning (MALL) Technology. In: International Journal of Environmental and Science Education, vol. 11, n. 15, pp. 8562-8571. E-ISSN 1306-3065.

MERRITT, S. 1984. Negative Political Advertising: Some Empirical Findings. In: Journal of Advertising, n. 13, pp. 27-38. ISSN 0091-3367.

MOKSHANTSEV, R.I. 2007. Psikhologiya reklamy. Moskva: INFRA-M; Novosibirsk: Sibirskoe soglashenie. ISBN 5-16-000135-2. ISBN 5-8479-0014-7.

PLOTNIKOVA, S.N. 2008. Yazykovoe, diskursivnoe i kommunikativnoe prostranstvo. In: Vestnik IGLU: sb. nauch. statej, n. 1, pp. 131-136. ISSN 1997-0730 POCHEPCOV, G.G. 2001. Teoriya kommunikacii: ucheb. posobie. Moskva: Vakler. ISBN 5-87983-101-9, 966-543-062-9, 966-543-048-3

THOMSON, O. 1977. Mass Persuasion in History: An Historical Analysis of the Development of Propaganda Techniques. Edinburgh: Paul Harris Publishing. ISBN 0904505162, 9780904505160.

VERDONK, P. 2002. Stylistics. Oxford: Oxford University Press. ISBN 0-19437240-5

VOL'F, E.M. 1986. Otsenochnoe znachenie i sootnoshenie priznakov «khorosho / plokho». In: Voprosy yazykoznaniya, n. 5, pp. 98-106. ISSN 0373-658X

VOL'SKAYA, N.N. 2008. "Neputevye zametki" dlya neputevykh telezritelej? In: ZHurnalistika i kul'tura russkoj rechi, n.3, pp. 20-24. ISSN 2222-1492.

WITOSH, B. 2005. Linguistic Study of Genres. Problematic Aspects. Katowice: Publisher University of Silesia. ISBN 83-226-1495-0

ZHELTUHINA, M.R. 2003. Tropologicheskaya suggestivnost' massmedial'nogo diskursa: o specifike rechevogo vozdejstviya tropov v yazyke SMI. Moskva Volgograd: IYA RAN, VF MUPK. ISBN 5-88234-568-5.

ZHELTUKHINA, M.R. 2014. Interkulturelle semantische und pragmatische Parallelen im modernen Mediendiskurs: der funktionale Aspekt. Interkulturalität unter dem Blickwinkel von Semantik und Pragmatik / Csaba Földes (Hrsg.) Beiträge zur

XLinguae, Volume 10, Issue 4, October 2017, ISSN 1337-8384, eISSN 2453-711X 
interkulturellen Germanistik; Bd. 5: Sammelbände. Tübingen: Narr. pp. 257-275. ISBN 9783823379058.

ZHELTUKHINA, M.R. - BIRYUKOVA, E.V. - GERASIMOVA, S.A. - REPINA, E.A. - KLYOSTER, A.M. - KOMLEVA, L.A. 2017a. Modern Media Advertising: Effective Directions of Influence in Business and Political Communication. In: Man in India, vol. 97, n. 14, pp. 207-215. ISSN: 0025-1569.

ZHELTUKHINA, M.R. - MOUZYKANT, V.L. - BARABASH, V.V. PONOMARENKO, E.B. - MOROZOVA, E.V. - MORI, S. 2017b. Russian and Japanese Younger Generations in Search for a New Media Product. In: Man In India, vol. 97, n. 3, pp. 223-236. ISSN: 0025-1569.

ZHELTUKHINA, M.R. - SLYSHKIN, G.G. - MUZYKANT, V.L. PONOMARENKO, E.B. - MASALIMOVA, A.R. 2017c. Functional Characteristics of the English and Russian Media Texts about the Sochi 2014 Winter Olympic Games: Political and Linguistic Aspects. In: XLinguae Journal, vol. 10, n. 3, pp. 83100. ISSN 1337-8384.

ZHELTUKHINA, M.R. - VIKULOVA, L.G. - KOVALEVA, N.A. RYANSKAYA, E.M. - FOMINA, ZH.V. 2017d. Symbolic Nature of Culture: Features of the English Floristic Symbolics in Modern Economic and Political Media Texts. In: Man in India, vol. 97, n. 14, pp. 61-71. ISSN: 0025-1569.

ZHELTUKHINA, M.R. - VIKULOVA, L.G. - MIKHAYLOVA, S.V. BORBOTKO, L.A. - MASALIMOVA, A.R. 2017e. Communicative Theatre Space in the Linguistic and Pragmatic Paradigm. In: XLinguae Journal, vol.10, n. 2, pp. 85100. ISSN 1337-8384.

ZYUBINA, I.A. - MATVEEVA, G.G. - ZHELTUKHINA, M.R. - SLYSHKIN, G.G. - SHEVCHENKO, A.V. 2017. Forensic Prosecutor's Speech as a Speech Genre. In: XLinguae Journal, vol.10, n. 3, pp. 312-323. ISSN 1337-8384.

Words: 4909

Characters: 34241 (19,02 standard pages)

Associate Prof. Nadezda N. Volskaya, PhD.

Faculty of Journalism

M.V. Lomonosov Moscow State University

Mokhovaya Street 9/1

125009 Moscow

Russia

navolskaya@yandex.ru

Assistant Prof. Liudmila A. Borbotko, PhD.

Institute for Foreign Languages

Moscow City Teacher Training University

5 b Maly Kazenny per.

105064 Moscow

Russia

ludmilaborbotko@gmail.com

Prof. Marina R. Zheltukhina, DrSc.

Institute for Foreign Languages

Volgograd State Socio-Pedagogical University

Lenin Prospect 27

400066 Volgograd

Russia

zzmr@mail.ru 
Associate Prof. Milana E. Kupriyanova, PhD.

Faculty of Philology

Peoples' Frendship University of Russia

Mikluho-Maclay 10/2

117198 Moscow

Russia

milana.k@mail.ru

Associate Prof. Anna Yu. Ilina, PhD.

Faculty of Philology

Peoples' Frendship University of Russia

Mikluho-Maclay 10/2

117198 Moscow

Russia

kafedra_fl_rudn@mail.ru 